\title{
CONSTITUIÇÃO DE SI E ESCRITURA: O GESTO OTOBIOGRÁFICO
}

\author{
Polyana Olini ${ }^{1}$
}

\section{Vontade de vir a ser}

Escrever-se está longe de descrever-se, pois escritura deixa pelo caminho a afirmação da verdade para afirmar a vida: escritura-se. Com Nietzsche, o campo de forças permite um processo contínuo de mudança, concebidas como variações de intensidade. Essas diferenças pressupõem a existência de pontos ou singularidades que constituem polos de condensação: "meras diferenças de poder ainda não poderiam sentir a si mesmas como tais: há de existir um algo que quer crescer, que interpreta cada outro algo que quer crescer a partir de seu valor" (NIEZSCHE, 2008, §643). Esse algo pode determinar essas variações de força, interpretandoas em relação a seu próprio valor.

A individualidade, como o princípio da diferenciação da força, configura o processo de constituição de si como sistemas de vida. Se a individuação precede a diferenciação de valores próprios, então, individuação em si deve ser constituída por indivíduos dotados de individualidade, ou seja, com uma qualidade interna que permite interpretar variações de potência. É a existência de uma multiplicidade de singularidades individualizantes no universo, cada um com sua própria individualidade, é que é possível criar, conhecer e constituir a si mesmo como totalidades orgânicas.

Para Derrida, a capacidade de tornar-se o que se é está ligada à nossa forma de ler, de escrever, de lidar com nossos estados corporais e com nossos instintos em luta de forças internas. Para isso, ele desconstrói as distinções feitas entre fala e escritura, vida e morte, presença e ausência pelo conceito de différance. É a vida e o vivente que criam e interpretam a escritura e a leitura, sem origem ou fim.

\section{Conceito-método}

Derrida (2009) traça concepções de assinatura, liberdade acadêmica e rastros biológicos, biográficos e tanatológico. Apontam para a elaboração cuidadosa de respostas sobre algumas leituras políticas e pedagógicas de Nietzsche. Ele viveu tempos em que o nome do filósofo intempestivo é associado aos piores tipos de política. Assim, o que permanece em Otobiographies é a constante advertência de que a vida afirmativa pode ser transformada em uma forma reativa e degenerativa de políticas, entregue à presunção da metafísica da presença.

A visão de (auto)biografia, defendida por Derrida, não é para ser de forma alguma confundida com a chamada vida do autor e o corpus de acidentes empíricos que compõem esta vida, mas o biográfico, uma vez que é autobiográfico, atravessa a fronteira entre vida-obra.

O conceito de otobiografia, como conceito-margem, não é hermenêutico. Como gesto, quer escutar a dynamis da margem vida-morte, texto-escritura, biografia-trabalho filosófico, considerando o jogo como seu movimento que se farta em usar e-ou-sim-não. Como conceitométodo, a otobiografia não descobre, não desvenda e nem desvela, mas desconstrói. Quando nos aproximamos do texto por esse gesto, somos atravessados por seu estilo. A partir daí, o texto opera uma relação de sedução com o leitor.

\footnotetext{
${ }^{1}$ Mestre em Educação pela Universidade Federal de Mato Grosso. Doutoranda do Programa de Pós-Graduação em Educação da Universidade Federal do Rio Grande do Sul, com pesquisa na Linha Filosofias da Diferença e Educação. Pesquisadora participante, na Área Temática Constituição Estilos de Individuação, do grupo de pesquisa Estudos de Filosofia e Formação do PPGE/IE/UFMT. E-mail: polyanaolini@gmail.com.
} 


\section{Método-labirinto}

Monteiro (2007) trata sobre os temas nietzschianos operados por Derrida. Propõe a criação de um conceito e, com base neste conceito, um método otobiográfico, que consiste em investigar as vivências implicadas nos escritos. Fundamentando na ideia de que toda produção escrita é formativa, o pesquisador concebe um conceito operador, que denomino gesto otobiográfico.

Otobiografia é mais um neografísmo derridiano, inspirado nas inúmeras possibilidades da phoné como différance, isto é, palavra escrita diferida temporal e espacialmente. Na língua francesa, as palavras autobiographie (autobiografia) e otobiographie (otobiografia), ao serem pronunciadas, não possuem diferenças fonéticas perceptíveis.

Derrida (2001) indica os desvios e as proximidades intelectuais e afetivas entre ele e Deleuze. Um dos desvios é o pensamento de que a filosofia consiste em criar conceitos, feita a ressalva de que o tenha feito sem nenhum caráter antipático, assim como o faço agora. Apenas achei pertinente citar esse detalhe porque, no mesmo texto, Derrida denomina suas diferenças com Deleuze meramente como gestos, estratégias e modos diferentes de filosofar sobre ideias, na maioria das vezes perturbadoramente semelhantes. $\mathrm{O}$ uso da palavra gesto me parece explicar melhor o empenho otobiográfico, como estratégia de ouvir, pensar e assentado na obra de Derrida e, é claro, em seu título.

O gesto otobiográfico se fundamenta na metáfora da escuta aliada à do labirinto. Em uma mesa-redonda na Universidade de Nebraska, tratando do texto de Otobiografias, Derrida ressalta que "o gesto consiste da escuta, enquanto falamos, o mais acuradamente possível, a voz de Nietzsche. Mas isso não significa que ela seja simplesmente recebida. Para escutá-la e entendê-la, é preciso, também, produzi-la" (Mcdonald, 1988, p. 51), já que a assinatura de Nietzsche possui forma e força próprias. Derrida brinca com a otofisiologia: "quando fala do ouvido de Nietzsche, recreia-se em lembrar do labirinto" (MONTEIRO, 2007, p. 473). O gesto otobiográfico é conceito e metáfora do ouvido e na escuta das vivências.

Se o processo de constituição de si é tido ao modo de sistemas de vida que caracterizam a individualidade dos seres, de que modo devemos pensar as vivências como parte deste processo que excede o interno e o externo? Como as vivências estão ligadas à escritura?

Dois aforismos nos ajudam a pensar:

"Viver é inventar" (NIETZSCHE, 2004, §119). As vivências podem ser definidas como momentos, em nossas vidas, que provocam o crescimento destes instintos. Nesse sentido, o ponto da frase anterior é explicativo: esses momentos não são caracterizados por nada, além disso, e ponto! Isso está longe de pensar em vivências transcendentais que nos ensinam a aprender com erros ou a acreditar em bens maiores.

"Ninguém pode escutar mais das coisas, livros incluídos, do que aquilo que já sabe. Para aquilo a que não se tem acesso por vivência, não se tem ouvido" (NIETZSCHE, 1995, §1). O ato de otobiografar vai além do que se chama de hermenêutica, pois é contínua imposição de instintos, alimentados por vivências, agem como totalidade vital, que se apropriam da escritura criando, inventando significados plurais. Dito de uma vez, é método-criação. Aqui os processos de decifração e de compreensão de um significado tomam conotações distintas, afastando este gesto da hermenêutica: interpretar é criar valores, dar espaço para a excedência dos sentidos.

Como labirinto, os sentidos não são encontrados, eles se perdem. Ao estilo derridiano, o sentido excede e restringe. Nas trilhas do excesso e da falta, em trilha enviesada, se caminha. Odisseia sem moral. Ariadne sem novelo. Método como jornada sugerida por Tirésias sem manteia. O método otobiográfico de inspiração desconstrutora, denuncia a presença do sentido de um texto, pois o vê como recalque, como expressão do alicerce logofonocêntrico, e passa a 
buscar no descentramento o abandono de um significado transcendental, que seja livre de cadeias significantes.

\section{Referências}

DERRIDA, Jaques. Espolones: los estilos de Nietzsche. (Trad. M. Arranz Lázaro). Valencia: Pre-textos, 1981.

. Otobiografías: La enseñanza de Nietzsche y la política del nombre proprio. (Trad. Horacio Pons). Buenos Aires: Amorrortu, 2009. (Colección Nómadas).

. The work of mourning. Chicago and London: The University of Chicago Press, 2001.

MCDONALD, Christie. The ear of the other: otobiography, transference, translation: texts and discussions with Jacques Derrida. Lincoln: University of Nebraska Press, 1988.

MONTEIRO, Silas Borges. Otobiografia como escuta das vivências presentes nos escritos. In: Educação e Pesquisa, vol. 33, n. 3, São Paulo: Faculdade de Educação da Universidade de São Paulo, 2007.

NIETZSCHE. Ecce homo: como alguém se torna o que é. (Trad. Paulo Cezar de Souza). São Paulo: São Paulo: Companhia das Letras, 1995.

. Aurora: reflexões sobre os preconceitos morais. (Trad. Paulo Cezar de Souza). São Paulo: Companhia das Letras, 2004.

Vontade de poder. (Trad. Marcos S. P. Fernandes e Francisco José Dias de Moraes).

Rio de Janeiro: Contraponto, 2008. 